cultivating an understanding of what scientific explanations are. Naturally, if some among their audiences prefer supernatural explanations, toleration is in order. But not equal time.

\section{Organizing change}

Last week was formative, even traumatic, for the British government's arrangements for the sponsorship of technical innovation. It began with a report from the Advisory Council for Applied Research and Development on operations of the National Research Development Corporation, set up immediately after the Second World War as a means of exploiting inventions not taken up by private industry, and which has been for the past two decades the chief means of exploiting inventions arising within publicly supported laboratories, in universities and elsewhere. The week finished with public confirmation that the corporation is to be merged, as soon as possible, with the other and more controversial arm of the British government's patronage of industrial innovation - the National Enterprise Board. By all accounts, both organizations have been working closely together since the beginning of the year, when Sir Frederick Wood, then chairman of the corporation, was appointed chairman of the board as well. Now there is to be legislation to formalize a merger.

Politically, the rearrangement will have considerable advantages. The National Enterprise Board is, for the present British government, a curious hangover from the past. It is the survivor of the organization set up in 1965 by Sir Harold Wilson's Labour government, which is best remembered for having spent a great deal of public money persuading companies to merge with each other, sometimes successfully (as with General Electric Company), sometimes unsuccessfully (British Leyland). The present British government, ideologically opposed to public intervention in private industry, has nevertheless found it necessary to keep the rump of the old organization if only as a means of disposing of the public investments that have accumulated over the years. But the government (like its supporters) has never been easy with this inherited embarrassment. It will obviously be of some assistance if the board can appear to disappear, and the name being canvassed for the new organization - the British Technology Corporation - may help in that direction.

The proposed merger nevertheless makes sense. Each of the proposed partners needs strengthening. The National Enterprise Board, accustomed as it is to persuading bankers to act in unfamiliar ways, is short of a knowledge of what technology is about. The corporation, on the other hand, knows a lot about technology but is financially unadventurous, perhaps because of its over-zealous avoidance of borrowing from the Treasury to enlarge its operations. In principle, then, the impending merger should provide an organization more effective than the sum of its parts. The combined organization may become the elusive ideal after which British governments have striven for decades - a cost-effective way of using public money to encourage industrial innovation.

This is why all those concerned with the merger should read the report of the advisory council with close attention. It is possible that the problem of supporting innovation with public funds has been transformed since the corporation and the board were first conceived. One of the complaints that the council makes against the corporation is that it has in the past been too concerned that innovations coming its way should already be protected by patents. Somebody convinced that his new mousetrap will drive all other mousetraps from the market must first take out a patent and then, if his invention has not been snapped up by a mousetrap manufacturer, must ask the corporation to help with the cost of development. The trouble, the council properly says, is that in present circumstances many of the most interesting innovations consist not of patentable inventions but of know-how, "intellectual property". The complaint against the National Research
Development Corporation is indeed softened by a recognition that the corporation has recently been changing its ways, but plainly a merger with the board will help in this direction, if only because the board is more used to backing companies than patents.

Another of the council's complaints against the present arrangements bears on the relationship between the National Research Development Corporation and the universities and government laboratories. Hitherto, the corporation has had a right to first refusal of all innovations springing from the use of public funds. It has not always been imaginative in its dealings with innovators in these places. Rightly or wrongly, many in this constituency have a sense of grievance. The advisory council now suggests that this monopoly should be dispensed with, on the grounds that there should be more than one source of support for promising ideas. This argument is not accepted by the National Research Development Corporation (which claims already to have acted on the council's other recommendations). The reluctance is understandable but unjustifiable.

\section{Too much TV?}

The geosynchronous orbit is a scarce natural resource. There is only one orbit about the Earth in which objects will appear to be stationary from any point on the surface of the Earth. Obviously such a unique facility should be used sensibly. By good fortune, national ambitions to put satellites into this orbit are moderated by international negotiation and agreement within the International Telecommunications Union, originally established to see that terrestrial broadcasting systems did not interfere with each other. Aware of the technical possibility that geosynchronous satellites might be used for broadcasting television signals directly into people's homes (with the help of a small dish antenna), the union called an international conference in 1977 to carve up the geosynchronous orbit among its member states. The report of the British Home Office (which combines responsibility for the regulation of domestic broadcasting with that for such matters as the administration of British prisons) shows that the decisions then taken should be reconsidered.

The report (see page 277) is stimulated by the British Government's wish not to waste the five channels of television broadcasting doled out to in 1977. But this is an awkward time. The Home Office has just suffered the trauma of deciding that British television-watchers should be allowed a fourth channel, to be run under the supervision of the Independent Broadcasting Authority and financed from the profits of the commercial television companies who occupy one of the three existing channels of domestic television. Much of the Home Office's strategy on broadcasting in the past few months has been designed not to harm the profits of the commercial television companies, for that would jeopardize the "success" of the fourth channel. Only this can explain the caution with which would-be operators of cable networks are being licensed. The offer of a further five television channels is not a gift but an embarrassment.

The British Government deserves some sympathy in its embarrassment. The 1977 decision that each member of the International Telecommunications Union should be entitled to five geosynchronous direct-broadcasting channels was illconsidered and premature. Then, as now, it was not clear what balance that will eventually be struck between direct broadcasting to people's homes and the more efficient use of the geosynchronous orbit by means of broadcasts to community antennas. The American members of the union had the sense to opt out of the 1977 decision, and will consider how the geosynchronous orbit should be carved up among themselves only in 1983. Elsewhere, the mere availability of the new channels is certain to lead to a waste of effort in the development of a broadcasting system whose economic place in the market cannot be determined while national governments (the British included) decline to let competing and complementary systems, such as cable networks, develop freely. 